\title{
Elderly mistreatment
}

M. Huki Zukhrufan ${ }^{1}$, Roza Mulyana ${ }^{2}$

'PPDS Ilmu Pen y aki Dalam Faku tas Ked okteran Universtas Andalas/RSUP Dr. M. Djamil Padang ${ }^{2}$ Su bbagian Geriatri Bagian Ilmu Pen y aki Dalam Faku tas Ked okteran Univ ers tas Andalas/RSUP Dr. M. Djamil Padang

Email : hukizılh rufan@gmail.com Tep :+628116643212

Submi tted : 21 -01-2020, Reviewe r: 25-01-2020, Accepted: 26-01-2020

\begin{abstract}
Abstrak
Elderly mistreatment atau salah perlakuan terhadap orangtua merupakan segala tindakan disengaja yang menyebabkan kerusakan atau bahaya yang serius terhadap orang lanjut us ia. Salah perlakuan juga dapat didef in is ikan sebagai kegagalan untuk memenuhi kebutuhan das $\mathbf{x}$ dan melindungi orang lanjut us ia dari bahaya. Salah perlakuan ini pada umumnya disebabkan oleh care giver atau pengasuh. Salah perlakuan terhadap orang lanjut usia dapat dicurigai terkait dengan berbagai sindrom geriatri yang terjadi Telah dilaporkan kasus salah perlakuan terhadap pasien perempuan berus ia 90 tahun. Pasien datang dalam keadaan perubahan kesadaran. Kec urigaan salah perlakuan pada pas ien ini karena adanya multipel sindrom geriatri pada pasien, seperti gangguan kognitif, infeks i dan malnutrisi serta imobilis as i dengan komplikas i ulkus dekubitus Pada pemeriks aan fs ik ditemukan konjungtiva anemis, luka lecet pada daun telinga, pada auskultasi paru dijumpai ronkhi bas ah halus nyaring di kedua lapangan paru dan edema pada kedua tungkai serta ulkus dekubitus yang multipel. Pasien juga mengalami mahutrisi. Pada pasien dilakukan penanganan komprehens if meliputi perbaikan status gizi, pemberian antibiotika, peraw atan luka ulkus dekubitus, dan kons eling keluarga.
\end{abstract}

Kata k unci: Elderly mistreatment, sindrom geriatri

\begin{abstract}
Elderly mistreatment or misuse of parents is all intentional actions that cause serious damage or danger to the elderly. Mistreatment can also be defined as failure to satisy basic needs and protect older people f rom harm. This mistreatment is generally caused by a caregiver. Mistreatment of elderly can be suspected to be related to various geriatric syndromes that occur. Mistreatment case of 90 years old f emale patient have been reported. The patient comes in a state of changing consciousness. Suspicion of mistreatment in these patients due to multiple geriatric syndromes in patients, such as cognitive impairment, infection, and malnutrition and immobilization with complications of decubitus ulcers. On physical examination conjunctiva anemic was found, abrasions on the earlobe, on the auscultation of the lungs found wet crackles on the both lung fields and edema of both limbs and multiple decubitus ulcers. the patient is also malnourished. In patients, comprehensive treatment includes improv ement of nutritional status, antibiotics, treatment of decubitus ulcer, and f amily counseling.
\end{abstract}

Keywords: Elderly mistreatment, geriatric syndrome 


\section{PENDAHULUAN}

Salah perlakuan terhadap orangtua adalah segala jenis hal yang me mbaha yaka $n$ termasuk tindaka n kasar, pengabaia $\mathrm{n}$, ekspbitasi serta kejahatan terhadap ha $\mathrm{k}$ azazi manus ia. Fa ktor $r$ is iko unt uk timbu ln ya sala $h$ perla kuan pada us ia lanjut ya itu us ia yang sangat lanjut, kurangnya akses terhadap akses kesehatan, rendahnya pendapatan, is olasi s os ial, status minor itas, rendahnya pendidikan, rendahnya kemampua $\mathrm{n}$ fungs iona l, sa lah guna zat ole h pra murawat atau pender ita, gang guan ps $\mathrm{kolog}$ is, $\mathrm{r}$ iwa yat keja hatan atau kekejaman da lam ke luarga, kele laha $\mathrm{n}$ dan frustasi pramurawat, serta gangguan kognitif. ${ }^{1,2}$

Jenis - jenis salah per lakuan pada us ia lanjut me liputi pengania yaan $\mathrm{f}$ is ik, pengaba ian fis ik, pe ngania yaan psikologis, pengan ia yaan dan pengaba ian $f$ inans ial ata $u$ materia l, ke jahatan terhadap ha $\mathrm{k}$ azazi manusia.

Pengania yaan $f$ is ik me ncakup tinda kan ke jahatan yang me nyebabka n nyer $\mathrm{i}$, trauma, ganggua $\mathrm{n}$, atau pe nyakit sepert $\mathrm{i}$ memukul, menendang, mend orong. Pengabaian $\mathrm{f}$ is ik memiliki $\mathrm{c}$ iri khas berupa ke ga ga a n pra murawat untuk menyia pka $n$ barang - barang atau pelaya nan yang dibutuhka $n$ untuk dapat berfungs i optimal atau untuk menghindar i bahaya. Pengania yaan ps ikolog is ada lah kekerasan terhadap menta 1 orangt ua sehingga menimbulka $\mathrm{n}$ kesedihan ya ng menda la $\mathrm{m}$, seperti ancaman dan caci maki. 1,2

Pengabaian ps ikologis merupaka $n$ kegagala n untuk menyediakan stimulas i sosia 1 bagi oragtua yang tidak mandir i. Pengania yaan fina ns ial atau material mencakup sa lah gu na pe ndapatan atau sumber finans ia latau pe ng has ilan ole $h$ orang $\mathrm{h}$ in atau perawat. Pengabaian $\mathrm{f}$ inans ia 1 atau materia 1 meru pakan ke ga ga lan men ggu naka $n$ dana atau sumber dana yang diperlukan unt uk menopang atau pemulihan kesehatan dan kesejahteraan us ia la njut. Keja hatan terhadap hak azazi manus ia ter jadibila orang yang merawat atau mengawasi us ia lanjut mengabaikan hak - hak orang berusia lanjut dan ke mampuan unt uk menga mbil keputusan bagi mereka (kebebasan pribadi, kekayaan pribadi, ke inginan berkumpul, berbicara, privas i, memberikan suara), seperti mengambil hak milik pribadi orangtua., ${ }^{1,2}$

Deteksi adanya salah perlakuan sangat penting karena terkait dengan berbaga $i$ sindrom geriatri ya ng umum terdapat ya itu de presi, deme ns ia, jatuh disertai frakt ur panggul, dan ulkus de kubitus. Menge na li adan ya salah per lakua $\mathrm{n}$ seringka li sulit. Orang ber us ia lanjut mungkin tak dapat memberikan infor masi karena adanya gangguan kognitif. ${ }^{1,2}$

Riwayat seringkali sulit didapat dari korba n, karena takut akan balas dendam pela ku. Orangtua seringka li takut ditempatkan di fasilitas perawatan dan beberapa lebih ba ik me milih diper lakukan tidak benar di rumah sendiri daripa da pindah ke tempat $\mathbf{b}$ in. Orang yang diper lakukan salah ser ingka li datang dengan ke luhan somatik. Keluha $\mathrm{n}$ yang samara tau membin gungka $n$ dapat men un jukkan ind ikasi salah per lakuan. Pada pemeriksaan $\mathrm{f}$ is ik pada kasus pengania yaan pa da orangtua dapat dijumpai fraktur atau dis lokas $\mathrm{i}$, hseras $\mathrm{i}$, abrasi, luka ba kar, memar, per darahan di daerah ge nita lia, salah guna obat. Sedangkan pada kasus pengaba ian dapat dijumpa $i$ kakeksia, hygiene ya ng bur uk, cara berpaka ian ya ng tidak sesua i, ga ng guan mobilitas, gangguan sensor is, gang guan komunikas i (ha mbatan sensor is atau kognitif), ke lemahan, ulkus dekubitus dan kontraktur. $^{1,2}$

\section{ILUSTRASI KASUS}

Telah dirawat seorang pasien perempuan us ia 91 tahun di Bagian Penya kit Dalam RSUP Dr. M. Djamil Padang se jak tangga 125 Apr il 2019 de ngan ke luha $\mathrm{n}$ utama perubaha n kesadaran se jak 7 hari yang la lu. Perubahan kesadaran terjadi per lahan, pas ien kadang bisa dia jak komunikas $i$ dengan keluarga, da $n$ terkadang bicara meracau dan tidak nyambung. Pasien juga menga h mi lecet yang telah me njadi tuka $\mathrm{k}$ di ping gang, pinggul dan punggung sejak 2 bulan yang 
h lu. Pasien me nga lami imobilisasi di tempa t tidur se jak 5 bulan yang la lu. Penurunan nafsu makan se jak 1 bula $n$ yang la lu. Pasien makan tidak teratur dan hanya menghabiskan

$1 / 2$ pors $i$, pasie $n$ terkadang makan $2-3$ kali sehari. Sembab pada tangan dan tungka $\mathrm{i}$ sejak 1 bulan yang blu. Nyeri pada tanga $n$ dan kaki seja $\mathrm{k} 1$ bulan ya ng la lu, sehingga tangan dan kaki menjadi sulit untuk digerakkan.

Gangguan penglihatan sejak 1 bulan yang la lu, pasie $\mathrm{n}$ mas ih da pat me lihat namun kabur. Batuk se jak 3 minggu ya ng h lu, batuk hilang timbul, diserta i dahak berwarna put ih, batuk berdarah tida $\mathrm{k}$ ada, batuk tida $\mathrm{k}$ diserta $\mathrm{i}$ sesak nafas. Demam sejak 1 hari yang la lu, demam hilang timbul, tidak tinggi da $\mathrm{n}$ tida $\mathrm{k}$ mengg igil, de mam tidak disertai ker ingat banyak. Pasien sebelumn ya tela $\mathrm{h}$ dirawat $\mathrm{di}$ rumah sakit swasta 2 minggu yang la lu kare na tukak yang nyeri di se lur uh tubuh, dirawat selama 2 minggu, na mun karena tidak ada perba ikan ke luarga pas ien meminta untuk dirujuk.

Pasien menikah dan memiliki 1 orang suami dan 10 orang anak (4 orang anak lakilaki dan 6 orang anak perempua n). Pasien adalah seorang ibu ruma $h$ tangga da $n$ juga berdagang makanan. Almarhum suami pasien beker ja sebaga $\mathrm{i}$ pedagang. Pasie $\mathrm{n}$ tingga 1 bersama anak ke -8 (menga h mi keterbelaka ngan mental) se jak 5 bulan yang la lu. Sebelumnya pasie $n$ tingga 1 bersama anak bungsu pasie n, namun karena anak bungsu pasien menikah 5 bulan yang la lu, maka ia me mutuskan untuk tingga 1 bersama suami Pasien pa ling dekat de ngan anak bungsunya. Se jak pas ien ditingga lkan ole h anak bungsunya pasie $n$ menja di cepat marah dan lebih ba nyak tidur. O leh karena pasie $n$ yang gampang marah dan tidak mau untuk dirawat maka anak pasien yang la in menja di enggan untuk mengurus pas ien, sehingga pasien lebih banyak diurus ole $\mathrm{h}$ anaknya yang menga lami keterbe lakangan menta 1 , sedangkan ana $\mathrm{k}$ pasien yang $\mathrm{h}$ in hanya mengunjungi pas ien da lam waktu s ingkat, sekedar untuk mengantarkan makanan.

Sejak 5 bula $n$ yang la lu pasie $n$ hanya berbaring di tempat tidur dan tidak me lakukan akt ivitas apapun, pasie n makan disuapkan oleh anak pas ien dan dima ndika $n$. Pasien BAB dan BAK di tempat tidur yang telah dilapis i ole h per lak. Anak pas ien ha nya membersihkan tubuh bagia $\mathrm{n}$ de pan pas ien saja jika terkena BAB atau BAK, se dangkan tubuh bagian belakang tidak ada dibersihkan.

Sebelum sakit, pasie $\mathrm{n}$ masih bisa me lakukan akt ivitas sehari hari. Pasien kurang aktif da lam kegia tan sos ial dan lingkungan. Pasien tida $\mathrm{k}$ beker ja, pas ien menda patkan bia ya hidup dar i anak-a nak nya, terutama anak ke 4. Sebe lum pas ien menga la mi perubahan kesadaran, makan $3 \mathrm{x}$ sehari namun, semenjak menga hami perubaha $\mathrm{n}$ kesadaran, pas ien hanya makan setengah dari porsi normal

Pada saat datang rawatan, kesadaran pasien delirium, dengan tekanan darah $160 / 100 \mathrm{mmHg}$, frekue nasi nafas $23 \mathrm{x} / \mathrm{me}$ nit, frekuensi nadi $110 \mathrm{x} /$ menit, dan suhu tubuh 37.7 CC. Body mass in dex pas ien $15.5 \mathrm{~kg} / \mathrm{m} 2$, pasien termasuk kategori underweight. Pada pemer iksaan $\mathrm{f}$ is $\mathrm{k}$ didapatkan konjungtiva anemis da n kedua le nsa mata keruh. Pada pemer iksaan te linga luar terdapat luka lecet pada aur ikula (D). Pada pemeriksaan $\mathrm{f}$ is $\mathbf{k}$ paru didapatkan $r$ onkhi basah halus nyar ing di ke dua lapangan par u. Pemeriksaan ekstremitas dite muka $\mathrm{n}$ edema bilateral Pada pasien ditemukan ulkus decubitus di regio coxa 1 (D) berukuran $10 \times 10 \times 5 \mathrm{~cm}$ dan $5 \times 2 \times 1$ $\mathrm{cm}$, regio pate llar $(\mathrm{S})$ berukura $\mathrm{n} 5 \mathrm{x} 2.5 \mathrm{x} 1 \mathrm{~cm}$. Pasien juga menga lami kontrakt ur kedua tungka $\mathrm{i}$ Ger iatric Comprehens if Assesment sukar dilakuka $\mathrm{n}$ pada pasie $\mathrm{n}$ ini. Penapisan depresi da $n$ mini menta 1 state examination (MMSE) sukar dinila i pada pas ien. Activity Daily Living (ADL) Barthel pasien termasuk kategor i ketergantunga $n$ total. Mini nutr itiona 1 assessment (MNA) pasen termasuk kategori mahutrisi

Pemeriksaan penunjang menunjukkan $\mathrm{Hb} 7,4 \mathrm{gr} / \mathrm{dL}$, e ukos it 13.270/mm3, hitung jenis leukosit $0 / 1 / 3 / 85 / 9 / 2$, trombosit 495.000/mm3, MCV $88 \mathrm{fL}, \mathrm{MCH} 29 \mathrm{pg}$, MCHC 33\%, Retikulos it $4.8 \%$. Pada pemer iksaan ga mbaran darah tepi didapatkan anemia sedang normos it ik normokrom dengan polikromas i, leukositosis dengan 
netrof ilia shif $\mathrm{t}$ to the right, trombos it os is. Pada pemeriksaan kimia klinik didapatka $\mathrm{n}$ albumin $1,9 \mathrm{~g} / \mathrm{dl}$. Pemeriksaan ur in rut in didapatkan leukos it ur in 8-10/ LPB dengan yeast $(+)$. Benzidin test $(+)$ pada pasien in $\mathrm{i}$. Pemeriksaan e lectrocardiography (EKG) memberikan kesan low voltage. Pemeriksaa $n$ rontge $\mathrm{n}$ thoraks memberikan kesan bronkopne umonia. Pemeriksaan kultur sput um denga $n$ has il no growth, kultur pus klebs ie lla pneumonia yang sensitif dengan amikac in, dan kultur ur in dite mukan candida sp.

Pasien diberikan terapi ya itu antibiotik ceftriaxon inj $2 \times 1 \mathrm{gr}$, evof loxac in inf $1 \times 500 \mathrm{mg}$, metr onidazol inf $3 \times 500 \mathrm{mg}$, drip amikacin $2 \times 500 \mathrm{mg}$, fluconazol inf $1 \mathrm{x}$ $200 \mathrm{mg}$, transf us i PRC, n-acet yls iste in $3 \times 200$ mg (p.o), parasetamol 3x500 (p.o), ambdipin 1x5 mg. C. lytre 4 x sehari ODS Pasien diberikan nutrisi energi $1100 \mathrm{kkal}$, protein $40 \mathrm{gr}$, lemak $25 \%$, dengan nutr is i ora 1 beru pa nasi lunak 2x300 kkal (target $80 \%$ ), bubur put ih $1 \times 200 \mathrm{kka} 1$ peptamen $2 \times 150$ kka l, put ih te lur 2 but ir/ har i Nutr is i parenteral: Aminof luid $500 \mathrm{ml} 24$ ja m. Mikr onutr ien : vitamin C 2x0 mg, Zinc 1x $20 \mathrm{mg}$. Pasie n juga diber ikan P lasbumin $20 \% 100 \mathrm{ml}$ 1x per hari Pada pas ien dilakukan re dresing 1 kali sehari de ngan sa lf ia lucet plus 1 ka li sehar i, penggunaan kasur de kubitus dan mobilisas $\mathrm{i}$ dini berupa miring kiri dan mir ing kana $\mathrm{n}$ setiap 3 jam serta lingkup gerak sendi pasif.

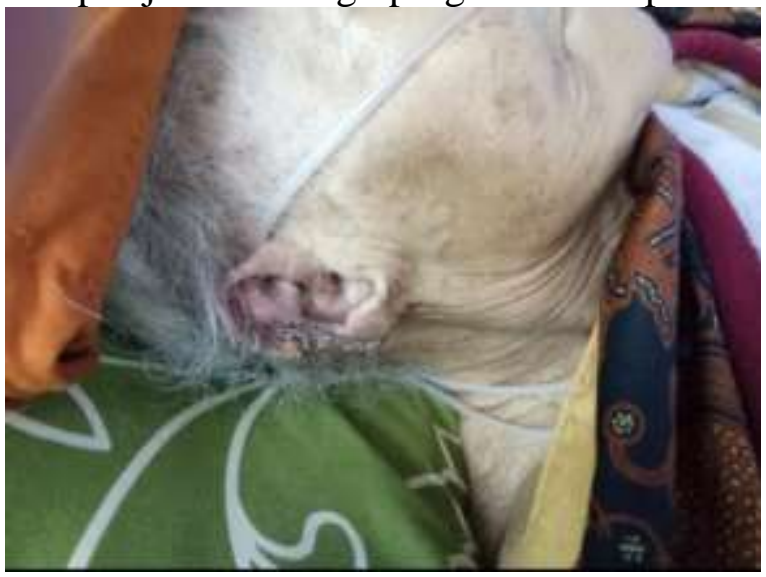

Gambar 1. Luka lecet pada aurikula

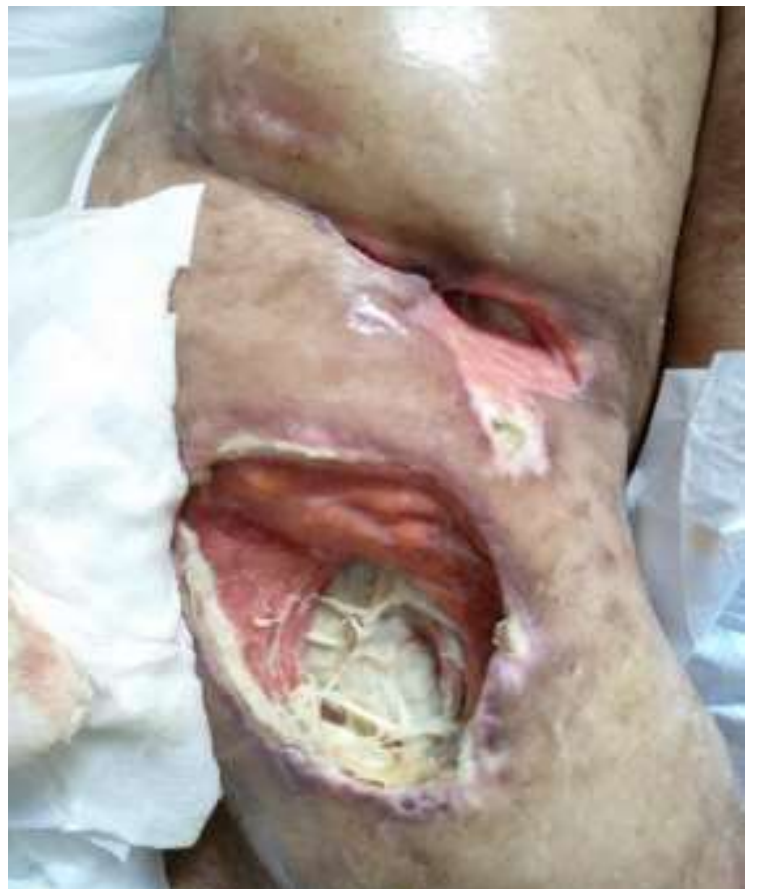

Gambar 2. Ulkus dekubitus grade III - IV pada bokong pasien

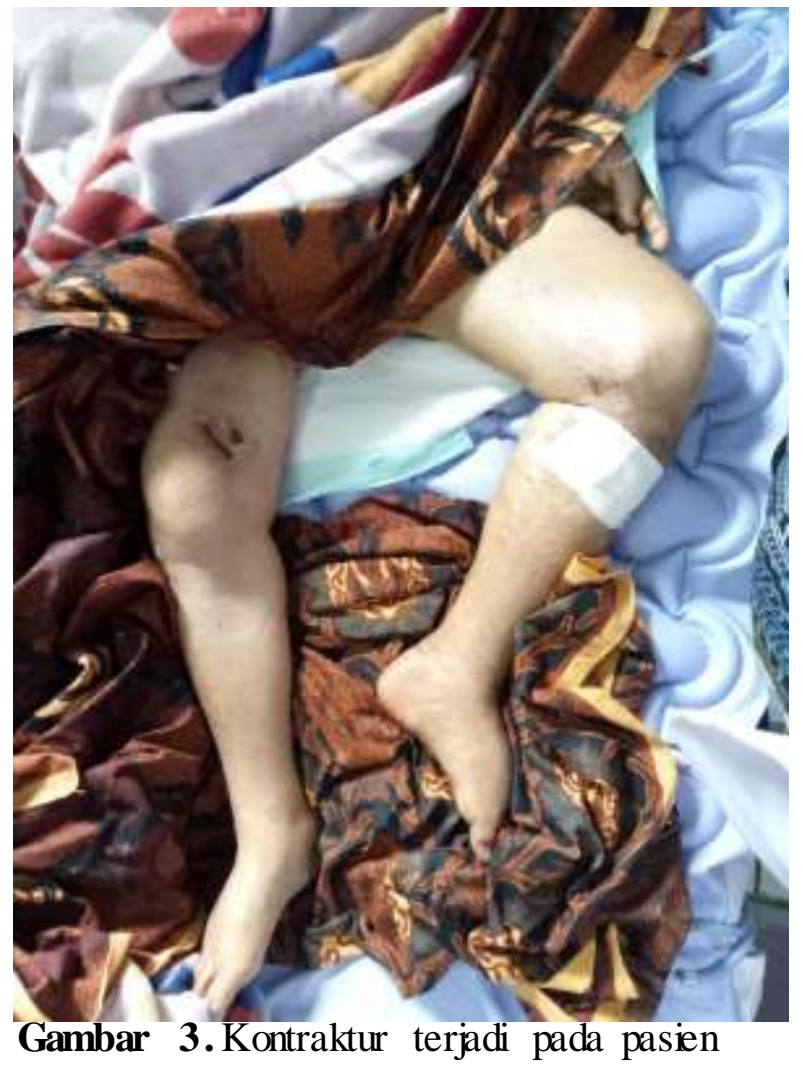

\section{Dis k usi}

Telah dirawat seorang pasien perempuan us ia 91 tahun di Bagian Penya kit Dalam RSUP Dr. M. Djamil Padang de ngan diagnos is akhir sindrom de lir ium akut, multiple ulkus dekubitus grade III - IV, 
hospita lize d acquired pneumonia, infeks $\mathrm{i}$ saluran ke mih, a nemia sedang nor mos it ik nor mokrom ec perdarahan akut, hipertens $\mathrm{i}$ stg I ec esensia 1, imobilisasi denga $n$ ketergantungan tota 1, ma lnutr is i, inkontinens ia urin, katarak imatur ODS.

Pasien ini menga lami salah perla kua n atau elderly mistreatme nt. Elder ly mistreatment adalah segala jen is ha 1 yang membahaya kan termasuk tindakan kasar, pengaba ian, eksploitasi, serta keja hatan terhadap hak azazi ma nus ia. Jenis salah perla kuan pa da usia lanjut dapat berupa pengaba ian $\mathrm{f}$ is $\mathrm{ik}$, penga baia $\mathrm{n}$ ps $\mathrm{k}$ olog is, pengaba ian finans ia 1 ataupun mater ia 1 Johannesen et al (2016) mene liti faktor ris iko elderly mistreat ment, dan menemuka $n$ empat fakt or $r$ is iko uta ma kasus ini ya itu; lans ia itu sendir $\mathrm{i}$, pe laku, hubunga $\mathrm{n}$ dala $\mathrm{m}$ keluarga dan lingkungan. ${ }^{3}$

Faktor ris iko dari lans ia itu sendir i dapat berupa gangguan kognitif, ganggua $n$ perila $\mathrm{ku}$, penyakit psikiatr ik atau masalah ps ikologis , ketergantungan fungs ional, kesehatan fis ik ya ng buruk, pe ndapatan rendah, trauma atau riwa yat pengania yaan dan suku atau etnis. Ganggua n kognitif sebagai sa lah satu faktor $r$ is iko dibukt ka $n$ dari beberapa studi yang dilakuka $\mathrm{n}$ pada populas i umum, studi lans ia yang membutuhkan bantuan dalam aktivitas sehari-hari da n studi lans ia dengan demens ia. Studistudi tersebut me nunjukka n bahwa gangguan fungs i kognitif beris iko menyebabkan ter jadinya salah per lakuan. Sementara itu, gangg uan per ila ku pa da lans ia yang menjadi faktor $r$ is iko sa lah per lakua $n$ me liput $\mathrm{i} s$ ika p provokatif, agres if atau menola $\mathrm{k}$ perawatan. Hal tersebut dibukt ika $\mathrm{n}$ pada beberapa studi yang dilakuka $n$ pada lans ia yang membutuhkan bantuan da lam akt iv itas sehari hari dan pada studi lans ia dengan deme ns ia. Faktor $r$ is iko salah perla kuan pada pasie $n$ ini ya itu gang guan kognitif dan sikap provokatif. ${ }^{4}$

Disharmoni ke luarga atau hubungan yang buruk dan konf lik da lam keluarga juga merupa kan faktor $r$ is iko tejadinya sa lah perla kuan pada lans ia. Pada pasien ini terdapat konflik internal terhadap perawatan pasien, yakni tidak ada anak pas ien yang dengan sukare la merawat pasien. Faktor ris iko sala h perla kuan pada lans ia dari aspek lingkungan disekitar pas ien diantaran ya ya itu dukungan sosial yang rendah dan tinggal bersama orang la in. Hal tersebut berdasarkan hasil studi pada populas i umum dan lans i yang membutuhkan bantuan dari aktivitas sehari-hari ${ }^{4}$

Salah perlakua $n$ pada pas ien ini dapat dicegah jika keluarga pasien mema hami kondis i perubahan fis ik dan ps ikologis pa da lans ia. Peran keluarga merupa kan ja lan keluar untuk kasus ini Pada pasien akan dilakukan home care, tempat ting ga 1 pas ien dapat dengan mudah dija ngkau oleh tenaga kesehatan, sehing ga direncanakan perawatan luka setiap hari ole h tenaga medis, dan keluarga tela $\mathrm{h}$ bersepakat unt uk merawat pasien ini secara paripurna. Elder ly mistreatment dapat menimbulkan ber bagai masalah medis pada pasien ini.

Pasien ini didiagnos is dengan sindr om de lir ium akut. Pasien mas ih dapat kontak namun tidak nya mbung, dan terkadang pasien ge lisah. Sindrom de lir ium merupa kan kond is i yang sering dijumpai pada pasie $n$ geriatri di ruma h sakit. Sindrom ini ser ing tida $\mathrm{k}$ terdiagnos is de ngan ba $\mathrm{k}$ saat pasien berada di rumah (akibat kurangnya kewaspadaan keluarga) maupun saat pasien sudah berada di unit gawat darurat atau un it rawat jalan. Ge ja la dan tanda yang tidak khas merupa kan salah satu penyebabnya. Setidakn ya $32 \%$ - $67 \%$ dari s indrom ini tidak terdiagnos is oleh dokter, pada hal kond is $\mathrm{i}$ in $\mathrm{i}$ dapat dicegah. Faktor pre dispos is i yang ditemukan pada pasien in i antara la in us $\dot{\mathbf{a}}$ sangat la njut dan gangguan sensor ium Sedangka n, faktor pencetus pada pasien antara hin pneumonia, infeks i saluran kemih, hip onatre mia, dan perubahan ps ikolog is serta perubahan lingkungan. ${ }^{5}$

Geja la sindr om de lirium terjadi secara akut dan berfluktuatif, dari hari ke hari dapat terjadi perubahan ge jala secara bergantian. Gejala yang membedaka $n$ dengan demens ia yaitu perhatia $\mathrm{n}$ pasien sangat terganggu, pasien tidak mampu 
mempertahankan konsentras i maupun perhatian pada satu topik pembicaraan. ${ }^{6}$

Penatalaksanaan sindr om de lir ium bertujuan untuk mengatas i faktor pencetus dan faktor predisposisi. Secara umum penangana $n$ yang bersifat suportif sanga $t$ penting dalam pengelolaan pasien sindrom delir ium, baik untuk pengobatan maupun pencegahan. Asupan nutr is $i$, keseimbanga $n$ cairan dan elektrolit, ke nyamana $\mathrm{n}$ pasie $\mathrm{n}$ harus diupa yakan seoptima 1 mungkin.

Keberadaan anggota ke luarga atau yang selama ini merawat akan sangat berperan dala $m$ memulihkan or ie ntasi dan sedapat mungkin rua ngan pas ien tenang dan cukup penerangan. ${ }^{6}$

Pada pasien kemungkinan de pres $\mathrm{i}$ belum dapat dis ingkir kan. Depresi merupakan penyakit dengan tampilan gejala yang tidak spesif ik pada populas i geriatri. Faktor ps ikosos ial berperan sebagai faktor predisposisi depresi. Orangtua seringkali menga lamu periode kehilanga $\mathrm{n}$ orang orang yang dikas ihi. Fa ktor kehila ngan in i dapat meningkatkan kerentanan terhadap depresi dengan berkura ngnya kemaua $\mathrm{n}$ merawat dir i serta hilangnya ke mandirian. Kehilangan penghasila $\mathrm{n}$ dan dukungan sos ia 1 juga menjadi faktor predis pos is i pas ien lanjut us ia menga lami depres i Depresi dapat memperberat penyakit medis da n sebaliknya penyakit medis dapat memperberat depresi. ${ }^{7}$ Pasien juga menga lami gangguan sensor is yaitu katarak imatur ODS, sehingga pas ie n menjadi terisolasi dan berujung depresi

Imobilisas $\mathrm{i}$ dapat me nimbulka $n$ komplikas $\mathrm{i}$ medis la in pada pasien, sepert $\mathrm{i}$ infeks i, ulkus dekubitus, inkontinens ia, hipoalbumine mia, dan lainnya. Imobilisasi mungkin menyebabkan proses degeneras i yang terjadi pada sebagian besar siste $\mathrm{m}$ organ Imobilisas i dikaitkan dengan terjadinya pneumonia dan infeks i saluran kemih pada pasie $\mathrm{n}$ ini Akibat imobilisas $\mathrm{i}$ retensi sputum dan aspirasi lebih mudah terjadi pada pasien geriatri. Pada pos is $\mathrm{i}$ berbar ing otot diafragma dan interkosta 1 tidak berfungsi dengan baik sehingga gerakan dinding da da juga menja di terbatas yang menyebabkan sputum sulit keluar.
Kond is $i$ ini disertai dengan daya pegas (recoil) e lastik yang sudah berkura ng (kare na proses menua) yang me mudahkan us ia lanjut untuk mengalami pneumonia. ${ }^{8}$

Hospita lized acquired pne umonia (HAP) terjadi pada pas ien ini. Faktor ris iko HAP pada pasien ini yaitu usia yang lebih dari 60 tahun, kadar a lbumin serum yang rendah dan ma hutr is $\mathrm{i}$ Pasien mungkin menga la mi late onset HAP, ya itu HAP yang terjadi sete lah 5 hari atau lebih masa rawatan dan lebih sering disebabkan oleh patogen multi drug resistant (MDR). Faktor ris iko MDR pada pasien ini me liputi riwayat rawatan lebih dari 2 hari di rumah sakit. Diagnosis HAP sulit ditegakkan pada pasien karena gejala klinis pneumonia pada pasien us ia lanjut sering tidak khas. Perubahan menta 1 status dapat menjadi ge ja la klins yang paling umum pada pasien usia lanjut. ${ }^{9}$

Pemberian antibiotik harus segera diber ikan pada pasien usia lanjut dengan HAP, tanpa menungg u hasil kultur. Pasien yang diber ikan ant biotik $4-8$ ja m pertama akan men ga lami peningkatan ke langsungan hidup/ da ya sur viva l. Terapi antibiotik yang diter ima pasien dalam 2 mingg $u$ terakhir tetap dapat diber ikan sa mpa i menungg u hasil kultur, dan jika memungkinka $\mathrm{n}$ hindari penggunaan ke lompok antimikr oba yang sama. Perbaikan klin is pa da umumn ya akan tampak da lam $2-3$ hari, dan terapi tetap dilanjutka n minima 1 da a $\mathrm{m} 7-8$ hari, kecuali jkka terjadi perburukan klinis. ${ }^{9}$

Aliran ur in juga terganggu pada pasien ini, akibat tirah baring ya ng ke mudian menyebabkan infeks i saluran kemih kbih mudah ter jadi Inkontine nsia ur in pada us $\dot{\mathbf{a}}$ lanjut ya ng menga la mi imobilisas i, umumnya disebabkan ketidakmampuan ke toilet, berkemih yang tidak sempurna, gangg uan stat us mental, dan gangguan sensasi kandung kemih. ${ }^{10}$

Pasien juga me nga lami infeks $\mathrm{i}$ saluran ke mih. Se la ma perawatan dirumah pasien me maka i popok dan tidak kerap diganti dengan yang bersih dan kering setelah popok penuh dengan BAK, sehingga daerah genita lia akan menjadi area ya ng ba $\mathrm{k}$ untuk bakteri penyebab ISK berkembang 
biak. Inkontinens ia ur in sering mer upaka $n$ ge ja h ISK pada penderita geriatr i Saat ini ant ibiot ik golonga $\mathrm{n}$ kuinolon merupaka $\mathrm{n}$ terapi pilihan empiris. ${ }^{11,12}$

$$
\text { Pasien ini juga mengalami }
$$

inkontinens ia urin. Dari allo ana mnes is didapatkan bahwa pasien sudah tidak dapat menahan BAK sejak 5 bulan yang lalu. Inkontinens ia urin seringka li tidak dilaporkan oleh pasien atau ke luarga, antara b in karena menganggap bahwa masalah tersebut merupakan masalah yang mema lukan atau tabu untuk diceritaka $n$, ketidakta huan mengena i masala h inkontinens ia urin, dan mengangga $p$ bahwa kondisi tersebut merupakan sesuatu yang wajar terjadi pada orang usia lanjut serta tidak perlu diobati Berbaga i komplikas i dapat menyertai inkontinens ia urin seperti infeks i saluran kemih, ke la inan kulit, dan decubitus. Pada pasien usia lanjut sering terjadi inkontine nsia tipe campuran.

Kombinas i antara inkontinens ia ur in tipe stres dan urgens $i$ yang paling sering ditemukan. Delirium dapat menyebabkan proses hambatan refleks miks i berkurang sehingga menimbulkan inkontinens ia yang bersifat sementara. ${ }^{13}$

Menurut The Nationa 1 Pressure Uker Advisor y Panel pasie $\mathrm{n}$ ini termasuk ke dala $\mathrm{m}$ ulkus dekubitus stage III dan IV. Terapi ulkus dekubitus pada pasien ini berupa pember ian antibiotik sistemik dengan regimen terapi yang ditujukan untuk gram pos itif, negative dan anaerob, pe nggunaa $n$ kasur antidekubitus yang disertai dengan repos is i setia p 3 - 4 ja m, dan perawatan luka dengan disertai pe mber ian antibiotik topika 1 sulfadiazin. Pada pasien juga te lah dilakuka $n$ konsultasi bedah untuk penutupan luka, namun karena usia pasien ya ng sa ngat lanjut dan kondis i pasien yang belum stabil ma ka pada pasie $\mathrm{n}$ dilakuka $\mathrm{n}$ tindakan konservatif saja. Pada pasien didapatkan $\mathrm{Hb} 7 \mathrm{~g} / \mathrm{dL}$ pa da saat masuk, hal ini disebabkan karena adanya manifestasi perdarahan pada ukus dekubitus pasien, dan pasien ditatala ksana dengan transfusi PRC dengan target $\mathrm{Hb} 10 \mathrm{~g} / \mathrm{dL}$. Pada pasien diber ikan pember ian vita min da $n$ mineral berupa vitamin $\mathrm{C}$ dan zinc untuk penyembuhan luka. Penelitian $\mathrm{C}$ hao et al (2013) mene mukan bahwa pe mberian vitamin c dan zinc berperan da am penyembuhan luka, ditandai dengan penur unan ukura n ulkus. ${ }^{14} \mathrm{Pada}$ kultur pus pasien ditemuka numan kle bsie lh pneumonia, sensitif dengan amikacin, sehingga pada pas ien dilakukan penggatian antibiotic dengan drip amikasin $2 \times 500 \mathrm{mg}$.

Berdasarkan penila ian status gizi, pasien ini me nga lami ma lnutr is $\mathrm{i}$ Kondis $\mathrm{i}$ gizi kurang paling sering bermanifestasi sebagai kurang ener gy prote in (KEP) yang ditandai dengan adanya penyusutan massa otot ya ng bermakna (wasting syndrome) dan IMT yang rendah pa da pe mer iksaan klin is serta hasil pemeriksaan biokimiaw i seperti albumin atau protein lain yang menurun. ${ }^{13}$

Pasien in i termasuk pas ien ber is iko tinggi unt uk menga lami refeeding syndr ome berdasarkan $\mathrm{kr}$ iter ia NICE 2006. Ole h sebab it u pada pasie $n$ diber ikan pemberian diet secara bertahap, dimulai denga n $80 \%$ dari total diet pas ien se lama 3 hari pertama dan dina ikkan secara bertahap dalam 7 hari sampai dengan kebutuhan penuh pasien. ${ }^{16}$

Hipoa lbuminemia pada pasien ini juga dika itkan de ngan imobilisas $i$ Imobilisas i akan mempengaruhi sistem metabolik dan e ndokr in ya ng a kibatn ya akan terjadi perubaha $n$ terhadap metabolis me zat gizi. Sa ah satu perubahan ya ng ter jadi adalah pa da metabolis me prote in. Kadar plasma kort is ol lebih tinggi pada us ia lanjut dengan imobilisasi sehingga meta bolis me prote in aka $n$ lebih rendah pada pas ien us ia lanjut denga $n$ imobilisas i. Keadaan tidak berakt ivitas dan imobilisasi se lama 7 hari akan me ningkatkan eks kresi nitrogen ur in Peningkatan ekskres i nitr ogen mencapai puncak denga $\mathrm{n}$ rata - rata kehilan gan $2 \mathrm{mg} /$ hari, sehingga pasien a kan menga la mi hipoprote ine mia dan edema. ${ }^{8,10}$

Pasien juga mender ita hipertens i esensia 1 Pasien tida $\mathrm{k}$ memiliki riwayat hipertens $i$ sebelumnya. Riwayat anggota keluarga hipertensi tidak diketahui Berdasarkan JNC - 8, ba hwa target te kanan darah pada pasie $\mathrm{n}$ us ia lanjut tan pa komorbid adalah < 150/ 90 mmHg. Pada pasien 
diber ikan terapi diet rendah garam da $n$ pember ian antihiperte nsi golonga $n$ calcium channe 1 bloc ker. Prinsip penata laksanaan hipertens i pada pasien us ia lanjut ya itu dengan pe mberian obat "start low and progress s low". Pasien hipertens i us ia lanjut sering menga la mi pengurangan e last is itas arteri American soc iety of hyperte ns ion dan JNC 8 merekomendas ika n penggunaan CCB sebagai terapi anti hipertensi pa da us ia lanjut, hal ini berka ita $n$ dengan keamanan obat pada pasien dan efe $\mathrm{kCCB}$ ya ng dapat me lebarka $\mathrm{n}$ arteri denga $\mathrm{n}$ mengurangi a liran ka $\mathrm{k}$ ium $\mathrm{ke}$ dala $\mathrm{m}$ se $\mathrm{l}$ sehing ga me nur unkan tekana $\mathrm{n}$ darah. ${ }^{17}$

Pada pasien seharusnya dilakuka $\mathrm{n}$ mobilisas i segera dan perba ika $n$ pos is i, dengan mempos is ikan pas ien denga $n$ berbaga i cara sehing ga pasien dapat berbar ing de ngan ditopa ng oleh sendi yang sama ketika pasien berada pada posis i berdir $\mathrm{i}$, seperti ke pala, punggung dan ekstremitas pada pos is i lurus; dan a nkle juga pada pos is $\mathrm{i}$ berdir $\mathrm{i}$, seperti ekstremitas da $\mathrm{n}$ kaki me mbentuk sudut 90 derajat. Namun pada pasie $\mathrm{n}$ te lah ter jadi kontraktur atau adanya hambatan pergerakan sendi, sehingga dianjurkan unt uk latihan sendi pas if, denga $n$ minima 1 peregangan dan pergerakan lambat, dapat dila kukan satu sa mpa i dengan dua kali sehari. ${ }^{18}$

\section{KESIMPULAN}

Elderly mistreatment harus dicurigai

pada pasie $\mathrm{n}$ dengan mutipe 1 sindrom geriatric. Elderly mistreatment pada umumnya disebabkan oleh pengasuh, dapat dicegah jika ada kesepakatan dan sukare $\mathbf{l a}$ keluarga dalam perawatan pasien.

\section{DAFTAR PUSTAKA}

1. Wang MX, Brisbin S, Loo T, Straus S. Elder abuse : an approach to identif ication, assessment and intervention. CMAJ. 2015;187(8):575 $-80$

2. Pillemer K, Burnes D, Riff in C, Lachs MS. Elder Abuse: Globa 1 Situation, Risk Factors, and Prevention Strategies. Gerontologist.
2016; 56(2):194 - 205

3. Johannesen M, LoGiudice D. Elder Abuse: A Systematic Review of Risk Factors in Community-Dwe ling Elders. AgeAgeing. 2013;42(3) 292-8

4. Ummi UM, Noto D. Faktor $R$ is iko dan Tata laksana Salah Perlakuan terhadap Orang Tua. Jurna 1 Penya kit Dalam Indonesia. 2016: $52-7$

5. Ratih I, Kuntjoro H, Siti S, Arya GR. Incidence and Predictors for De lir ium in Hospita lized Elder ly Patients : a Retrospective Cohor t Study. Acta Medica Indonesia. 2012: $290-7$

6. Czeresna Heriawan. Sindr om delirium. PAPDI. 2016: 3795 - 9

7. HC Sojono, Probosuseno, Nina KS. Depresi pada Pasien Us ia Lanjut. PAPDI. 2016: 3810 - 16

8. Wijaya PL, Siti S,Kuntjoro H. Management of immobilization and its complication for elder ly. Acta Medica Indonesia. 2008. $233-9$

9. Chao-Hsien Lee, Chien-Liang Wu. An Update on the manage ment of hospita 1 - acquired pneumonia in the elderly. Elsevier. 2008: $183-9$

10. Setiati S, Arya GR. Imobilisasi pada Usia Lanjut. PAPDI. 2016: 3758 -63

11. Czeresna Heriawan. Infeksi Saluran Kemih pada Geriatri Maj Kedokt Indon. 2005: $165-8$

12. Wahyudi ER. Prevalens i infeks i saluran kemih da n sebaran faktor risiko pada pasie $n$ us ia lanjut di RSCM. Jakarta: Departemen Ilmu Penyakit Dalam FKUI;2004.p.36

13. Fauci A, Kasper D, Longo D, Braunwald EH, S Jameson et al. Clin ica 1 problem of ag ing. Harrison's princ iple of inter mal medic ine. 18th ed. Mc Graw - Hill. 2011

14. Beth SM, Anne tte T, David H, Rongwe i F, Ngoc W et al Pressure ulcer treatment strategies. Annals. 2013: $39-46$

15. Setiati S, Purwita. Pedoman Nasiona 1 Asuhan Nutr is i pada Orang Usia Lanjut dan Pasien Geriatr i. PERGEMI. 2017: 11 
16. Nationa 1 Institute for Health and Clinica 1 Exce llence (NICE). Nutr ition support for adults: oral nutrition support, enteral tube feeding and parenteral nutrition. [internet] 2006. Available from https $/$ www.nice.org.uk/guida nce/cg32/chap ter/1-Guidance

17. Hasan Mujtaba, Iqbal Akhtar. Essentia 1 Hyperte nsion in Elder ly. Open J Cardiol Heart Dis. 2019: 1-9

18. Turpie AGG, Chin BSP, Lip GYH. Venous thromboembolis $\mathrm{m}$ : pathophys iology, c linica 1 feature, and prevention. BMJ. 2002;325:88 7-90. 